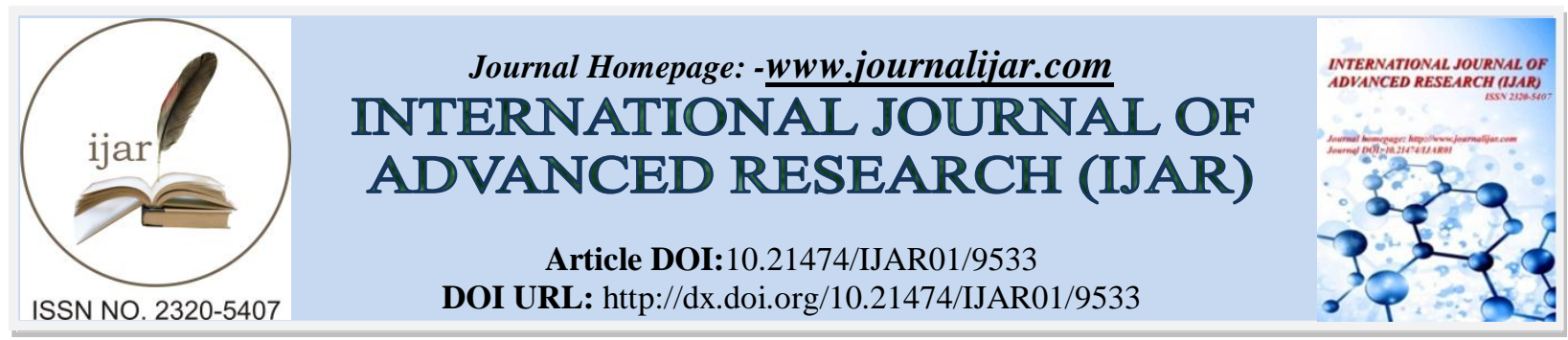

RESEARCH ARTICLE

\title{
THE USE OF BEHAVIOURAL ADVICE IN THE MANAGEMENT OF SEPARATION ANXIETY IN CANINES: A LITERATURE REVIEW.
}

Shen Jiaying ${ }^{1}$, Seah Jing Yan ${ }^{1}$ and Yap Qi Rou ${ }^{2}$.

1. Department of Research, Oei Family Clinic.

2. Yong Loo Lin School of Medicine, National University of Singapore.

\section{Manuscript Info}

Manuscript History

Received: 06 June 2019

Final Accepted: 08 July 2019

Published: August 2019

Key words:-

canine; separation anxiety; behavioural advice; dog.

\begin{abstract}
Canine separation anxiety is a prevalent and pertinent issue, making up the second largest group that behavioural clinics see. Various treatments have been devised in an attempt to manage this disorder, with varying success. This review aimed to consolidate the literature regarding the effectiveness of behavioural advice given to owners in the management of separation anxiety in their canines. Eligible studies were sourced through databases Scopus, ScienceDirect, Web of Science, Embase and Proquest. Ten studies were selected to be included in the literature review. Behavioural advice was found to lead to improvements in canine separation anxiety. Factors such as owner's compliance play a part in the treatment outcome. In conclusion, behavioural advice is effective in the management of separation anxiety in canines.
\end{abstract}

Copy Right, IJAR, 2019,. All rights reserved.

\section{Introduction:-}

Separation anxiety, defined as distress in the absence of an attachment figure ${ }^{1}$, is a prevalent ${ }^{2,7}$ issue. Canines with separation anxiety make up the second largest ${ }^{2}$ group that behavioural clinics attend to, accounting for 5\% to $40 \%$ of cases $^{3,4}$. In the absence of its owner, canines with separation anxiety may exhibit behaviour such as agitation (eg. restlessness, pacing, jumping), inappropriate elimination (urination and defecation), vocalisation (eg. whining, whimpering, howling, barking) and destruction (eg, escape attempts such as chewing, digging, scratching, and jumping through doors or windows). Less common symptoms include self-mutilation as well as aggression towards owner, prior to the owner's departure ${ }^{5}$. These unpleasant behaviours can easily damage the human-animal bond, consequently leading to rehoming, relinquishment ${ }^{6}$ or euthanasia $^{7}$ of these canines. Separation anxiety also affects the welfare of the affected $\operatorname{dog}^{8}$.

Factors predisposing canines to separation anxiety include its gender, breed, places of acquisition, family structure as well as owner's lifestyle ${ }^{5}$. Regarding acquisition, studies ${ }^{8,9,10}$ have shown that dogs acquired from shelters are more prone to separation anxiety. Shelters are often stress-inducing due to the limited space and interaction ${ }^{11}$ each dog has. Experiencing such stress for extended periods of time may sensitise the dog to later stresses, particularly separation related problems ${ }^{12}$.

Various methods have been employed to manage separation anxiety in canines. These methods include altering the surroundings of the dog (primarily to increase the dog's level of stimulation through physical activities), pharmacological treatment (medication and pheromones to reduce anxiety level of dog), behavioural treatment ${ }^{7}$, and 
educating the owner ${ }^{13}$. Pharmacological treatment does not address the root cause of the undesirable behaviour in dogs with separation anxiety ${ }^{5}$ and has even been found to have harmful effects ${ }^{3}$. Behaviour advice aims to accustom the dog to being alone and to reduce its reliance on the owner,13,20 and thus is believed to have a beneficial longterm effect on managing separation anxiety in canines ${ }^{14}$. Although behavioural therapy is becoming more prevalent ${ }^{15}$, and there is evidence that it is effective in the treatment of separation-related behaviour in canines, a review of the literature indicates a lack of comparative studies. This review aims to consolidate the literature regarding the effectiveness of behavioural therapy advice given to owners in the management of separation anxiety in their canines.

\section{Method:-}

\section{Search strategy}

Databases Scopus, ScienceDirect, Web of Science, Embase and Proquest were used in finding eligible studies for the literature review. Key terms "dog", "canine", "counsel", "advice", "behavioural advice" and "separation anxiety" were included in the search strategy. Language of publication was restricted to English.

\section{Selection process}

Relevance of the results from the searches were ascertained by reviewing each title and its abstract, if available. Articles which included specific behavioural advice given to owners for treatment and prevention of canine separation anxiety were shortlisted for review. Studies which used other forms of treatment in combination with behavioural therapy advice were also included to explore factors which may affect the effectiveness of behavioural therapy advice in the management of canine separation anxiety. Relevant articles were also selected from the bibliography of the shortlisted articles for discussion.

\section{Data extraction and analysis}

Data were extracted from the shortlisted articles to compare the behavioural therapy advice given to owners and its effectiveness. Size of study, duration of study, recruitment, intervention used, methodology of assessing changes to dog's behaviour, results and conclusion of the study were compared across the studies

\section{Results:- \\ Search results}

A total of 12 studies were found to be relevant and were shortlisted for the literature review. These studies are tabulated in Tables 1 and Tables 2 .

\section{Description of the studies}

Of the twelve studies found, seven used medication in combination with behavioural therapy advice ${ }^{7,15-18,32,33}$. Methodology used to assess changes to dog's behaviour were generally the same, with most (ten out of twelve) studies using a form of survey or questionnaire ${ }^{1,7,15-21,33}$. Only three studies used video recording of the dog's behaviour as a method of evaluating changes to dog's behaviour ${ }^{20-22}$ and one study ${ }^{32}$ using a cassette tape recording. The studies yield from a variety of countries, including the US, the UK, New Zealand and Spain. Dogs recruited for the studies also varied in breed, size, age and sex.

\section{Systematic desensitisation}

Systematic desensitisation refers to the "gradual and progressive introduction of the stimulus eliciting the phobia, in this case, the absence of the dog's owner" (Butler, 2011). The logic is that the dogs would not have an adverse reaction towards being left alone for a short period of time, and overtime, would get used to increasingly longer periods of being alone, thereby alleviating separation anxiety. Systematic desensitisation is often included as part of the behavioral advice given to owners with dogs suffering from separation anxiety.

Six out of twelve of the analysed articles included systematic desensitisation. Though the concept of systematic desensitisation was consistent among the six studies, the process of how systematic desensitisation was carried out differed slightly. For example, in Blackwell's et al 2016 study, owners were instructed to begin at a stage where the dog was not anxious, to take just a single step away from where the dog was lying, and then, very gradually (so slowly that the dog should not notice any difference between the stages nor ever became anxious), to increase the distance and time for which the owner and dog were parted. In Butler's et al, 2011 study, owners were instructed to start with a 5-min separation period, and gradually increase the period of separation in increments of 5 min until a 
period of 30-90 min was reached without recurrence of separation-related behaviour. If the dog displayed evidence of separation-related behaviour, owners were instructed to return to the longest period not previously associated with separation-related behaviour and to proceed more gradually. Instructions provided to owners in Lem's 2002 study were similar to Butler's et al, 2011 study, except starting departures were much shorter at 5 seconds. Systematic desensitization was advised as "short-term planned departures" in Cottam's et al, 2008 study.

Only one study (Butler et al, 2011) was able to conclude that systematic desensitisation led to the successful treatment of separation-related behaviour in $\operatorname{dogs}^{20}$

Studies on behavioural therapy advice combined with other treatment

There have been studies that favoured the use of medication and some which showed no additional benefits of medications.

Of those which favoured the use of medications in combination with behavioural modification plan are Iba' ñez and Anzola's 2009 study, Pineda et al's 2014 study, Lem's 2002 study and Karagiannis et al 2015 study. These studies found that medication, used in combination with behavioural modification plan results in better outcomes and improvements in canine separation anxiety than behavioural modification plan alone. In Iba'ñez and Anzola's 2009 study and Pineda et al's, 2014 study, antidepressant fluoxetine was administered together with benzodiazepine (diazepam and clorazepate dipotassium respectively), as the full anxiolytic effect of fluoxetine is not achieved until 4-5 weeks after initiation of treatment plan $^{23}$. The rapid acting benzodiazepine serves to control anxiety until antidepressant fluoxetine has had enough time to produce its therapeutic anxiolytic effect ${ }^{16,17}$. Both studies found fluoxetine to be an effective drug in reducing anxiety in dogs, whose efficacy can be increased by administering it together with diazepam and or clorazepate dipotassium. A temporary treatment of anti-anxiety drugs might be needed for canines with separation anxiety ${ }^{17}$ at the start of treatment as time is needed for canines to learn the behaviour modification ${ }^{24}$, which can be impeded by anxiety ${ }^{25}$. This would allow the canine to benefit more from the behaviour modification process. Karagiannis et al 2015 study found that the use of fluoxetine improves the dog's underlying affective state rather than simply restraining the dog's behaviour. This further supports the use of medications in combination with behavioural modification plan.

Of those which showed no additional benefits of medications in combination with behavioural therapy are Podberscek et al's 1999 study, Cottam et al's 2008 study and Takeuchi et al's 2000 study. Podberscek et al's 1999 study found that clomipramine, a tricyclic antidepressant, is not useful as an adjunct to behavioural therapy in treating separation-related behaviour problems in dogs. Similarly, Cottam et al's 2008 study found that owners whose dogs were administered medication were no more likely to report improvement in their dog's separation anxiety than owners whose dog's behavior modification plan did not include medication. This suggests that medication is not useful in the treatment of canine separation anxiety. Additionally, Takeuchi et al's 2000 study found that $52 \%$ of 23 dogs treated with medication for more than 1 month had improved by the time of follow-up telephone interviews, while $68 \%$ of 25 dogs treated with behavioural therapy alone had improved. This suggests that medication may not be that useful as a complement to behavioural therapy advice. This study also found adverse effects such as lethargy in two out of 15 dogs medicated with amitriptyline for more than one month.

Other than the use of medication, one study (Clark et al, 1993) used obedience training as a complement to canine behaviour counselling. The study found that the No Instruction group had significantly higher separation anxiety scores than both the Obedience group or the Time Instructed group ${ }^{22}$. The study's results did not show whether behavioural therapy or obedience training or both used together leads to improvement in canine separation anxiety.

\section{Mode of advice given}

One study (Cottam et al, 2008) compared the efficacy of faxed and in-clinic behaviouraladvice, and found that written communication without direct observation of the dog in the clinical setting is as effective as direct communication with a client and observation of the dog in a clinical setting ${ }^{18}$.

Among the remaining studies, seven studies used only verbal advice ${ }^{7,15-17,20-22}$, one study used only written advice ${ }^{19}$ while one study used both written and verbal ${ }^{1}$. The results revealed that verbal advice is an effective communication method. However, no comparison can be made between written and verbal advice due to the small sample analysed. 


\section{Assessing effect of behavioural advice}

Across the twelve studies, two assessed the efficacy of behavioural advice on the prevention of separation anxiety ${ }^{1,19}$. Results were collected post-test via a telephone survey instrument and a standardized survey method in one (Herron et al, 2014) and a postal questionnaire in the other (Blackwell et al, 2016).

Ten studies assessed the efficacy of behavioural advice on the treatment of separation anxiety ${ }^{7,15-18,20-22,32,33}$. Out of these ten studies, only three used video-recordings to record the dog's behaviour ${ }^{20-22}$ and one used cassette tape recordings $^{32}$. These recordings were later analysed. All eight studies but one employed the use of questionnaires pretest (to identify separation anxiety in dogs) as well as post-test (to assess whether separation anxiety in dogs has improved after behavioural therapy). The efficacy of behavioural therapy in the management of separation anxiety are assessed based on the results collected, in this case, the owner's assessment of their dog's behaviour. Although video recordings of the dog's behaviour were used to support report given by the owners ${ }^{21}$, there can still be bias or incorrect accounts ${ }^{19}$.

As such, future studies should use video recordings reviewed by an expert to assess changes in the dog's behaviour coupled with a standardized questionnaire for easier, direct comparison. This is especially in the case of assessing separation anxiety in canines as separation-related behaviour occurs only in the absence of the owner ${ }^{21}$.

\section{Compliance of owner}

A key factor affecting the efficacy of behavioural advice on the management of separation anxiety in canines is owner's compliance ${ }^{26}$. Studies analyzing owner's compliance found that owners only carried out aspects of the advice that required little time ${ }^{7}$ and were easy to follow ${ }^{19}$, such as leaving food in an enrichment toy for the dog. One study (Blackwell et al, 2016) suggested that written behavioural advice led to lower compliance as there was no interaction between the clinician and the pet owner. Owners might be unaware of the background of the advisor and the rationale behind the advice, and hence were less inclined to carry out the given advice ${ }^{19}$. This is supported by the Lincoln adherence intrusions record ${ }^{26}$, where trust in the clinician's advice is one of three key factors affecting compliance. The study also found that a high percentage of owners (77\%) did not comply with the advice of ceasing punishment although it required little effort, implying that owners find it hard to execute instructions that act against their emotions ${ }^{19}$. In one study (Pineda et al, 2014), it is suggested that increasing the dosage or frequency of clorazepate dipotassium to the canine improves owner's compliance. This is due to clorazepate dipotassium's rapid acting effect ${ }^{17}$, suggesting that seeing an improvement in the canine's behaviour could be a motivating factor for owners to comply with the behaviour modification plan.

\section{Limitations of the studies \\ Sample size}

Butler et al's 2010 study included only eight dogs showing separation related behaviour, Iba'ñez and Anzola's 2009's study included only seven dogs with separation anxiety and Pineda et al's 2014 study included only ten dogs with separation anxiety. The sample size used in these studies may not be representative of the population of canines with separation anxiety.

\section{Time}

Of the ten studies analysed, only one study (Herron et al, 2014) found that behavioural therapy had no significant effect on the management of separation anxiety ${ }^{1}$. However, this study also had the shortest duration of one month. Dogs that took part in the study might not have adapted to the behavioural therapy as behaviour modification requires time for dogs to learn ${ }^{24}$. This might have contributed to the biased result. Another study (Takeuchi et al, 2000) was carried out over 6 to 64 months. Such long duration diminishes reliability of owners' recollections of compliance and treatment success ${ }^{7}$.

\section{Setting bias}

Due to owners having varying personalities and the dogs living in different home environments, results from one setting are not always necessarily transferable to another.

\section{Discussion:-}

\section{Summary}

Behavioural therapy advice can be divided into three stages: 1)when at home, 2)when leaving, 3)when returning. It generally consists of systematic desensitization and counter-conditioning. Occasionally, medications were given to 
canines in conjunction with behavioural therapy treatment. External factors such as owner compliance can affect the efficacy of the treatment.

\section{Strengths and limitations}

While the search terms used were broad enough to identify most relevant studies, it is possible that some research were not identified. However, this is unlikely so as potential studies that could not be found through our search terms were hand searched from the bibliographies of the identified studies. Some studies were also excluded as language of publication was restricted to English, hence it is possible that some important studies were foregone.

\section{Comparison with existing literature}

This review has attempted to examine whether behavioural therapy helps in the management of separation anxiety in canines. 3 existing literature ${ }^{34-36}$ reviews have been found. An earlier review ${ }^{34}$ investigated the etiology of separation anxiety and concluded them to be: sex and neuter status, breed, genetics, other behavioural issues, personality of the owner and dog, attachment style of the dog, amount of obedience training, where the owners acquired the dog, where the family lives as well as factors that are not associated with separation anxiety. The review included the use of wearables (dog appeasing pheromone collar and compression vest) as a method of intervention. It also highlighted 2 categories that behavioural modification can be divided into: higher-effort procedures and lower-effort procedures. No further synthesis was made regarding whether the behavioural modifications were effective or not. The second review ${ }^{35}$ identified factors that predispose dogs to separation related behavioural problems and reviewed the different treatment strategies to relieve separation anxiety, including behavioural therapy. However, only 3 studies were used. Another review ${ }^{36}$ identified clinical signs of dogs with separation anxiety, signalment to separation anxiety, how diagnosis was made and reviewed the management plan. The management plan consists of environmental control, modifying behaviour, and medication. It has tabulated drugs commonly used in the treatment of canine separation anxiety, providing information on the drug class, oral dose and frequency. This review concluded that a treatment plan which improves the dog's environment when left alone, alters the owner-dog relationship and includes anti-anxiety medication is most successful. The current authors recommend isolating the components of behaviour therapy advice, in presence and absence of medications to determine which are effective.

\section{Implications for future research and recommendations}

There were several important findings we gathered across the studies:

1. It is noticed in one study ${ }^{7}$ that there is a proportion of canines whom responded well to the medication and the other whom did not. This could be due to the fact that not all canines exhibiting symptoms of separation anxiety are not affected for the same reasons ${ }^{31}$. As such, complete behavioural and medical history should be taken to determine specific behavioural diagnosis so that specific drug can be recommended to address the root cause of the canine's separation anxiety ${ }^{31}$.

2. It is suggested that the dosage of medication given, time of administration and frequency ofadministration are factors which affect the efficacy of medication on the treatment of canine separation anxiety ${ }^{7,17,31}$. For instance, different dosages of benzodiazepine results in different effects ${ }^{31}$. As such, further research can be done to determine when and how often medication should be administered and how the dosage can be tailored to each dog according to its condition to optimise the drug's efficacy.

3. Some antidepressants such as fluoxetine ${ }^{16,17}$ have a relatively long lag time (4-5 weeks) between initiation of treatment and achievement of its full anxiolytic effect, we recommend the administration of fast acting benzodiazepine as a supplement ${ }^{16,17,30}$ to antidepressants.

4. When verbal behaviour therapy is used, it can be crucial to note the profile of the advice provider to ensure client confidence in the advice provider is not undermined. Owners are more likely to adhere to the advice given if they understand the problem and rationale of treatment, which is closely linked with their confidence in the advice provider ${ }^{26}$. A survey found that private pet professionals, whom owners use as their sources of behavioural advice, felt their education was insufficient to advise owners in the management of separation anxiety ${ }^{27}$.

5. As owners only carried out aspects of the advice that required little time ${ }^{7}$, further research can be done to determine the optimal duration for behavioural therapy to be carried out so that owners will be more willing to comply with the given advice. Furthermore, it might be beneficial to break down the components of the behavioural therapy to determine whether one aspect of the behavioural advice is sufficient or all instructions are required in the management of separation anxiety in canines so that unnecessary instructions to owners can be removed ${ }^{20}$. This is important as dogs were significantly less likely to show improvement when owners receive more than five instructions compared to owners who received fewer than five instructions ${ }^{7}$. To 
corroborate whether systematic desensitization is the key to success of treatment for separation anxiety ${ }^{20}$, more research has to be carried out. Owners are also more likely to comply with the instructions if they are clear and simple, ${ }^{1}$ leading to greater comprehension of both their role and the aims of the behavioural therapy, and hence confidence in the advice giver ${ }^{26}$. It is pertinent for owners to understand the purpose of their actions, in the case of how systematic desensitisation should be used together with a special toy to ensure that the problem is not aggravated which would occur if the dog links the toy with anxiety ${ }^{4,28}$.

6. Lastly, a customised treatment programme which takes into account each owner's routines, capabilities and preferences has been shown to be more successful than a standard behaviour modification programme ${ }^{21}$. Such customisedbehavioural therapy advice can help in allowing for treatment to be implemented to an appropriate standard, increasing the chance of treatment success ${ }^{26}$.

\section{Conclusion:-}

This review article has consolidated the efficacy of behavioural therapy advice on the management of separation anxiety in canines. Behavioural therapy advice is useful in the prevention and treatment of canine separation anxiety and should be the first treatment option. More research can be done to find out which factors in the behavioural advice can be refined and how owner's compliance can be improved. Medications ${ }^{29}$, if needed, should be used as a complement to behavioural therapy advice.

Table 1:-A descriptive comparison of studies

\begin{tabular}{|c|c|c|c|c|c|c|c|}
\hline $\begin{array}{l}\text { Authors, } \\
\text { year and } \\
\text { country }\end{array}$ & Size & $\begin{array}{l}\text { Durati } \\
\text { on }\end{array}$ & Recruitment & Intervention & $\begin{array}{l}\text { How changes } \\
\text { to dogs' } \\
\text { behaviour } \\
\text { were assessed }\end{array}$ & Results & Conclusion \\
\hline $\begin{array}{l}\text { Herron et } \\
\text { al } \\
2014^{1} \\
\text { US }\end{array}$ & $\begin{array}{l}116 \\
\text { dogs }\end{array}$ & $\begin{array}{l}1 \\
\text { month }\end{array}$ & $\begin{array}{l}\text { Dog shelter, } \\
\geq 6 \text { months }\end{array}$ & $\begin{array}{l}\text { Counselling } \\
\text { session } \\
\text { (verbal), } \\
\text { written handout }\end{array}$ & $\begin{array}{l}\text { Telephone } \\
\text { survey } \\
\text { instrument } \\
\text { and a survey } \\
\text { completed by } \\
\text { owner. }\end{array}$ & $\begin{array}{l}\text { No significant } \\
\text { effect of } \\
\text { adoption } \\
\text { counseling on } \\
\text { the prevention } \\
\text { of separation } \\
\text { anxiety. }\end{array}$ & $\begin{array}{l}\text { Further } \\
\text { research } \\
\text { should be } \\
\text { carried out to } \\
\text { identify more } \\
\text { specific, } \\
\text { effective } \\
\text { prevention } \\
\text { instruments } \\
\text { for owners to } \\
\text { minimise the } \\
\text { development } \\
\text { of canine SA }\end{array}$ \\
\hline $\begin{array}{l}\text { Blackwel } \\
\text { let al, } \\
2016^{19} \\
\text { England }\end{array}$ & $\begin{array}{l}176 \\
\text { dogs }\end{array}$ & $\begin{array}{l}12 \\
\text { weeks }\end{array}$ & $\begin{array}{l}\text { Dogs of any } \\
\text { breed, sex, } \\
\text { age, size, or } \\
\text { neuter } \\
\text { status, } \\
\text { rehomed } \\
\text { from shelter }\end{array}$ & $\begin{array}{l}\text { Leaflets } \\
\text { (written) }\end{array}$ & $\begin{array}{l}\text { Postal } \\
\text { questionnaire } \\
\text { completed by } \\
\text { owner. }\end{array}$ & $\begin{array}{l}\text { Dogs in the } \\
\text { control group } \\
(38 \%) \text { were } \\
\text { more likely to } \\
\text { be reported by } \\
\text { owners as } \\
\text { showing signs } \\
\text { of SA/SRB } \\
\text { than those in } \\
\text { the treatment } \\
\text { group }(22 \%)\end{array}$ & $\begin{array}{l}\text { Written } \\
\text { advice } \\
\text { provided } \\
\text { appears to be } \\
\text { effective in } \\
\text { reducing the } \\
\text { development } \\
\text { of SRB after } \\
\text { rehoming }\end{array}$ \\
\hline $\begin{array}{l}\text { Clark et } \\
\text { al, } \\
1993^{22} \\
\text { US }\end{array}$ & $\begin{array}{l}30 \\
\text { dogs }\end{array}$ & $\begin{array}{l}13 \\
\text { weeks }\end{array}$ & $\begin{array}{l}\text { Dogs varied } \\
\text { in breed and } \\
\text { size, and } \\
\text { ranged in } \\
\text { age from } 3 \\
\text { to } 36 \\
\text { months }\end{array}$ & $\begin{array}{l}\text { Obedience } \\
\text { classes, review } \\
\text { outline and } \\
\text { lectures } \\
\text { (verbal) }\end{array}$ & $\begin{array}{l}\text { Video-camera } \\
\text { was used to } \\
\text { obtain pretest } \\
\text { and posttest } \\
\text { measures of } \\
\text { obedience } \\
\text { behaviour, } \\
\text { proximity, }\end{array}$ & $\begin{array}{l}\text { The Obedience } \\
\text { group showed } \\
\text { lower } \\
\text { separation } \\
\text { anxiety than } \\
\text { the No } \\
\text { Instruction } \\
\text { group. }\end{array}$ & $\begin{array}{l}\text { It might be } \\
\text { useful to } \\
\text { address which } \\
\text { behaviour } \\
\text { problems } \\
\text { correlate with } \\
\text { SA }\end{array}$ \\
\hline
\end{tabular}




\begin{tabular}{|c|c|c|c|c|c|c|c|}
\hline & & & & & $\begin{array}{l}\text { tactile } \\
\text { behaviour and } \\
\text { SA exhibited } \\
\text { by each dog. } \\
\text { Three judges } \\
\text { evaluated the } \\
\text { videotapes. }\end{array}$ & & \\
\hline $\begin{array}{l}\text { Cottam } \\
\text { et al, } \\
2008^{18} \\
\text { US }\end{array}$ & $\begin{array}{l}69 \\
\text { dogs } \\
\text { with } \\
\text { SA }\end{array}$ & $\begin{array}{l}\text { Avera } \\
\text { ge of } \\
21 \\
\text { month } \\
\text { s }\end{array}$ & $\begin{array}{l}\text { Clients of } \\
\text { veterinary } \\
\text { school }\end{array}$ & $\begin{array}{l}\text { (A); Faxed } \\
\text { handouts } \\
\text { (written), } \\
\text { follow-up } \\
\text { phone calls } \\
\text { (B): in-clinic } \\
\text { consultation } \\
\text { (verbal), } \\
\text { medication for } \\
\text { some }\end{array}$ & $\begin{array}{l}\text { Owners filled } \\
\text { in } \\
\text { questionnaire } \\
\text { to confirm } \\
\text { SA. Clients } \\
\text { were given the } \\
\text { opportunity to } \\
\text { re-rate the } \\
\text { severity of } \\
\text { their dog's } \\
\text { behavior in } \\
\text { the same } \\
\text { situations. } \\
\text { Owners were } \\
\text { asked one } \\
\text { question } \\
\text { regarding their } \\
\text { perception of } \\
\text { any change in } \\
\text { their dog's } \\
\text { behavior }\end{array}$ & $\begin{array}{l}\text { No significant } \\
\text { difference was } \\
\text { found between } \\
\text { the mean } \\
\text { difference } \\
\text { score of dogs } \\
\text { treated via } \\
\text { PetFax(41\%) } \\
\text { and those } \\
\text { brought to } \\
\text { clinic(39\%). } \\
\text { Owners who } \\
\text { administered } \\
\text { medication( } 83 \\
\%) \text { to their } \\
\text { dogs were no } \\
\text { more likely to } \\
\text { report } \\
\text { improvement } \\
\text { in their dog's } \\
\text { SA than } \\
\text { owners who } \\
\text { did not report } \\
\text { using } \\
\text { medication as } \\
\text { part of their } \\
\text { dogs' behavior } \\
\text { modification } \\
\text { plan( } 100 \%)\end{array}$ & $\begin{array}{l}\text { Written/verba } \\
1 \\
\text { communicatio } \\
n \text { without } \\
\text { direct } \\
\text { observation of } \\
\text { the dog in the } \\
\text { clinical } \\
\text { setting is as } \\
\text { effective as } \\
\text { direct } \\
\text { communicatio } \\
n \text { with a client } \\
\text { and } \\
\text { observation of } \\
\text { the dog in a } \\
\text { clinical } \\
\text { setting for } \\
\text { assessing and } \\
\text { managing } \\
\text { canine SA }\end{array}$ \\
\hline $\begin{array}{l}\text { Butler et } \\
\text { al, } \\
2010 \\
\text { New } \\
\text { Zealand }^{20}\end{array}$ & $\begin{array}{l}8 \text { dogs } \\
\text { with } \\
\text { SA }\end{array}$ & $\begin{array}{l}\text { Betwe } \\
\text { en } 1 \\
\text { and } 6 \\
\text { month } \\
\text { s }\end{array}$ & $\begin{array}{l}\text { Veterinary } \\
\text { referrals and } \\
\text { responses to } \\
\text { a newspaper } \\
\text { article }\end{array}$ & $\begin{array}{l}\text { Verbal } \\
\text { behavioural } \\
\text { advice }\end{array}$ & $\begin{array}{l}\text { A rating scale } \\
\text { was used to } \\
\text { measure the } \\
\text { owner's } \\
\text { subjective } \\
\text { rating of the } \\
\text { severity of the } \\
\text { SRB during } \\
\text { baseline and } \\
\text { treatment } \\
\text { separations. } \\
\text { All } \\
\text { vocalization } \\
\text { ratings were } \\
\text { undertaken } \\
\text { from tape- } \\
\text { recordings } \\
\text { made in the } \\
\text { owner's } \\
\text { absence. }\end{array}$ & $\begin{array}{l}\text { Systematic } \\
\text { desensitization } \\
\text { was successful } \\
\text { in reducing } \\
\text { both the } \\
\text { severity and the } \\
\text { frequency of } \\
\text { SRB by the end } \\
\text { of treatment or } \\
\text { follow-up. }\end{array}$ & $\begin{array}{l}\text { Systematic } \\
\text { desensitizatio } \\
\mathrm{n} \text { was the } \\
\text { critical } \\
\text { element in the } \\
\text { success of } \\
\text { treatment. } \\
\text { Speed of } \\
\text { progress and } \\
\text { final success } \\
\text { was not } \\
\text { related to how } \\
\text { consistent the } \\
\text { owners } \\
\text { applied } \\
\text { systematic } \\
\text { desensitizatio } \\
\mathrm{n} \text {, showing } \\
\text { that even } \\
\text { when owners }\end{array}$ \\
\hline
\end{tabular}




\begin{tabular}{|c|c|c|c|c|c|c|c|}
\hline & & & & & $\begin{array}{l}\text { Reliability } \\
\text { checks were } \\
\text { carried out by } \\
\text { an } \\
\text { independent } \\
\text { observer. } \\
\text { Progress } \\
\text { checks were } \\
\text { made every } 2 \\
\text { weeks. }\end{array}$ & & $\begin{array}{l}\text { apply } \\
\text { systematic } \\
\text { desensitizatio } \\
\mathrm{n} \\
\text { haphazardly, } \\
\text { it can still be } \\
\text { successful in } \\
\text { treating SRB } \\
\text { in dogs }\end{array}$ \\
\hline $\begin{array}{l}\text { Podbersc } \\
\text { ek et al } \\
1999^{15} \text {, } \\
\text { UK }\end{array}$ & $\begin{array}{l}49 \\
\text { dogs } \\
\text { with } \\
\text { SA }\end{array}$ & $\begin{array}{l}8 \\
\text { weeks }\end{array}$ & $\begin{array}{l}\text { Owners } \\
\text { with dogs } \\
\text { who were } \\
\text { referred to a } \\
\text { behavioural } \\
\text { consultant }\end{array}$ & $\begin{array}{l}\text { Dog's } \\
\text { behavioural } \\
\text { modification } \\
\text { plan(verbal) } \\
\text { Dogs were } \\
\text { given } \\
\text { clomipramine. }\end{array}$ & $\begin{array}{l}\text { Owners to } \\
\text { complete a } \\
\text { questionnaire } \\
\text { before } \\
\text { treatment and } \\
\text { three times } \\
\text { after treatment } \\
\text { Owners were } \\
\text { asked to rate } \\
\text { the } \\
\text { frequencies of } \\
\text { the dog's } \\
\text { general } \\
\text { behaviour, } \\
\text { attachment- } \\
\text { related } \\
\text { behaviour and } \\
\text { SRB. }\end{array}$ & $\begin{array}{l}\text { Dogs displayed } \\
\text { no } \\
\text { improvement } \\
\text { in most of their } \\
\text { SRB when } \\
\text { clomipramine } \\
\text { was used. Dogs } \\
\text { displayed } \\
\text { significant } \\
\text { improvements } \\
\text { in SRB except } \\
\text { 'appetite' when } \\
\text { behavioural } \\
\text { therapy was } \\
\text { used alone. }\end{array}$ & $\begin{array}{l}\text { Behavioural } \\
\text { therapy is } \\
\text { useful in } \\
\text { treating SRB } \\
\text { problems in } \\
\text { dogs. } \\
\text { Clomipramin } \\
\text { e is not useful } \\
\text { as an adjunct } \\
\text { to behavioural } \\
\text { therapy in } \\
\text { treating SRB } \\
\text { problems in } \\
\text { dogs. }\end{array}$ \\
\hline $\begin{array}{l}\text { Takeuchi } \\
\text { et al } \\
2000^{7}, \\
\text { US }\end{array}$ & $\begin{array}{l}52 \\
\text { dogs } \\
\text { with } \\
\text { SA }\end{array}$ & $\begin{array}{l}6 \text { to } 64 \\
\text { month } \\
\text { s }\end{array}$ & $\begin{array}{l}\text { Dogs for } \\
\text { which a } \\
\text { diagnosis of } \\
\text { SA was } \\
\text { made at the } \\
\text { veterinary } \\
\text { clinic }\end{array}$ & $\begin{array}{l}\text { Discharge } \\
\text { instructions(ver } \\
\text { bal) were given } \\
\text { to owners and } \\
\text { some dogs (23) } \\
\text { were given } \\
\text { medication in } \\
\text { combination } \\
\text { with } \\
\text { behavioural } \\
\text { therapy. }\end{array}$ & $\begin{array}{l}\text { Owners to } \\
\text { complete a } \\
\text { questionnaire } \\
\text { during initial } \\
\text { examination } \\
\text { and were } \\
\text { contacted } 6 \text { to } \\
64 \text { months } \\
\text { later by } \\
\text { telephone for } \\
\text { follow-up } \\
\text { interview on } \\
\text { the owners' } \\
\text { perception on } \\
\text { the treatment } \\
\text { outcome. }\end{array}$ & $\begin{array}{l}23 \text { dogs were } \\
\text { treated with } \\
\text { medication for } \\
\text { more than } 1 \\
\text { month; } 12 \\
(52 \%) \text { had } \\
\text { improved by } \\
\text { the time of } \\
\text { follow-up } \\
\text { telephone } \\
\text { interviews. } \\
\text { However, } \\
\text { owners felt that } \\
\text { the medication } \\
\text { was not } \\
\text { effective. } 17 \text { of } \\
25 \text { ( } 68 \%) \text { dogs } \\
\text { treated with } \\
\text { behavioral } \\
\text { therapy alone } \\
\text { had improved. }\end{array}$ & $\begin{array}{l}\text { Behavioural } \\
\text { therapy is } \\
\text { useful in } \\
\text { helping to } \\
\text { improve SA } \\
\text { in dogs. }\end{array}$ \\
\hline $\begin{array}{l}\text { Iba'ñez } \\
\text { and } \\
\text { Anzola } \\
2009^{16} \\
\text { Spain }\end{array}$ & $\begin{array}{l}34 \\
\text { dogs, } \\
\text { of } \\
\text { which7 } \\
\text { dogs } \\
\text { showe } \\
\text { d SA }\end{array}$ & $\begin{array}{l}10 \\
\text { weeks }\end{array}$ & $\begin{array}{l}\text { Dogs } \\
\text { diagnosed } \\
\text { with a } \\
\text { variety of } \\
\text { behavioural } \\
\text { disorders } \\
\text { from }\end{array}$ & $\begin{array}{l}\text { A behaviour } \\
\text { modification } \\
\text { plan (verbal) is } \\
\text { given to the } \\
\text { owner in } \\
\text { combination } \\
\text { with fluoxetine }\end{array}$ & $\begin{array}{l}\text { The clinical } \\
\text { history was } \\
\text { completed } \\
\text { using a } \\
\text { questionnaire. } \\
\text { Information } \\
\text { from the }\end{array}$ & $\begin{array}{l}\text { Dogs with SA } \\
\text { showed } \\
\text { improvement }(8 \\
5 \%) \text { in } \\
\text { symptoms. } \\
\text { There was a } \\
\text { positive }\end{array}$ & $\begin{array}{l}\text { Behaviour } \\
\text { modification } \\
\text { program, } \\
\text { combined } \\
\text { with } \\
\text { fluoxetine, } \\
\text { diazepam, as }\end{array}$ \\
\hline
\end{tabular}




\begin{tabular}{|c|c|c|c|c|c|c|c|}
\hline & & & $\begin{array}{l}\text { veterinary } \\
\text { clinic }\end{array}$ & and diazepam. & $\begin{array}{l}\text { owners was } \\
\text { collected at } 3 \\
\text { points in time } \\
\text { after the start } \\
\text { of therapy. } \\
\text { Response and } \\
\text { outcome were } \\
\text { determined by } \\
\text { the } \\
\text { supervising } \\
\text { veterinarian } \\
\text { and the owner. } \\
\text { Bipolar rating } \\
\text { scale was used } \\
\text { for owners to } \\
\text { rate how much } \\
\text { the dog's } \\
\text { behaviour } \\
\text { improved and } \\
\text { their } \\
\text { compliance } \\
\text { with the } \\
\text { treatment. }\end{array}$ & $\begin{array}{l}\text { correlation } \\
\text { between owner } \\
\text { compliance } \\
\text { with } \\
\text { the treatment } \\
\text { recommendatio } \\
\text { ns and the } \\
\text { values obtained } \\
\text { for } \\
\text { the } \\
\text { improvement } \\
\text { achieved for } \\
\text { each follow-up } \\
\text { period }\end{array}$ & $\begin{array}{l}\text { treatment for } \\
\text { dogs with } \\
\text { separation } \\
\text { anxiety leads } \\
\text { to } \\
\text { improvement } \\
\text { of } \\
\text { behavioural } \\
\text { disorders and } \\
\text { it may be a } \\
\text { faster and } \\
\text { more reliable } \\
\text { therapy than a } \\
\text { behaviour } \\
\text { modification } \\
\text { plan alone. } \\
\text { Owner's } \\
\text { compliance } \\
\text { with } \\
\text { treatment } \\
\text { recommendati } \\
\text { ons may also } \\
\text { help in } \\
\text { improvement } \\
\text { of symptoms. }\end{array}$ \\
\hline $\begin{array}{l}\text { Blackwel } \\
1 \text { et al } \\
2006^{21} \text {, } \\
\text { UK }\end{array}$ & $\begin{array}{l}\text { The } \\
\text { study } \\
\text { consist } \\
\text { s of } \\
\text { two } \\
\text { parts. } \\
1.50 \\
\text { dogs } \\
\text { with } \\
\text { SRB } \\
\text { proble } \\
\text { ms } \\
\text { (referre } \\
\text { d to as } \\
\text { 'trial } \\
\text { cases') } \\
\text { 2. } 29 \\
\text { dogs } \\
\text { with } \\
\text { SRB, } \\
\text { (referre } \\
\text { d to as } \\
\text { 'clinica } \\
1 \\
\text { cases') }\end{array}$ & $\begin{array}{l}12 \\
\text { weeks }\end{array}$ & $\begin{array}{l}\text { 1.Participan } \\
\text { ts for 'trial } \\
\text { cases' are } \\
\text { recruited } \\
\text { through } \\
\text { advertiseme } \\
\text { nts in } \\
\text { veterinary } \\
\text { surgeries, } \\
\text { and appeals } \\
\text { on local } \\
\text { radio } \\
\text { 2. The } \\
\text { 'clinical } \\
\text { cases' were } \\
\text { referred by } \\
\text { veterinary } \\
\text { surgeons. }\end{array}$ & $\begin{array}{l}\text { 1. For 'trial } \\
\text { cases', a } \\
\text { behaviour } \\
\text { modification } \\
\text { programme } \\
\text { (verbal) was } \\
\text { given to owner } \\
\text { 2. For 'clinical } \\
\text { cases', owners } \\
\text { receive } \\
\text { treatment plan } \\
\text { (verbal) } \\
\text { tailored to the } \\
\text { environment } \\
\text { and particular } \\
\text { problems of } \\
\text { their dog. }\end{array}$ & $\begin{array}{l}\text { Reports and } \\
\text { questionnaires } \\
\text { from the } \\
\text { owners and } \\
\text { remote video } \\
\text { recordings of } \\
\text { the dogs' } \\
\text { behaviour } \\
\text { when left } \\
\text { alone before } \\
\text { and after the } \\
\text { programme } \\
\text { started. }\end{array}$ & $\begin{array}{l}\text { 1. For 'trial } \\
\text { cases' } 56 \% \text { of } \\
\text { the owners of } \\
\text { dogs receiving } \\
\text { treatment } \\
\text { reported a } \\
\text { significant } \\
\text { improvement } \\
\text { after } 12 \text { weeks } \\
\text { of the } \\
\text { programme. } \\
\text { Treatments } \\
\text { under 'trial } \\
\text { cases' } \\
\text { produced } \\
\text { significant } \\
\text { improvements } \\
\text { in behaviour in } \\
\text { comparison } \\
\text { with the control } \\
\text { dogs. } \\
2 . \text { For 'clinical } \\
\text { cases',100\% of } \\
\text { owners } \\
\text { reported that } \\
\text { their dog's } \\
\text { behaviour had } \\
\text { improved and } \\
58 \% \text { of them } \\
\text { reported } \\
\text { significant }\end{array}$ & $\begin{array}{l}\text { Standard } \\
\text { behaviour } \\
\text { modification } \\
\text { programme } \\
\text { can be } \\
\text { effective for } \\
\text { the treatment } \\
\text { of SRB. The } \\
\text { slightly } \\
\text { greater degree } \\
\text { of } \\
\text { improvement } \\
\text { reported by } \\
\text { the } \\
\text { owners of } \\
\text { 'clinical } \\
\text { cases' } \\
\text { suggests that } \\
\text { a customised } \\
\text { treatment } \\
\text { programme } \\
\text { may have a } \\
\text { greater } \\
\text { chance of } \\
\text { success in the } \\
\text { treatment of } \\
\text { separation- } \\
\text { related } \\
\text { problems than } \\
\text { a general } \\
\text { treatment }\end{array}$ \\
\hline
\end{tabular}




\begin{tabular}{|c|c|c|c|c|c|c|c|}
\hline & & & & & & improvements. & plan. \\
\hline $\begin{array}{l}\text { Pineda et } \\
\text { al } \\
2014^{17} \text {, } \\
\text { Spain }\end{array}$ & $\begin{array}{l}36 \\
\text { dogs, } \\
\text { of } \\
\text { which } \\
10 \text { had } \\
\text { SA }\end{array}$ & $\begin{array}{l}10 \\
\text { weeks }\end{array}$ & $\begin{array}{l}\text { Dogs } \\
\text { diagnosed } \\
\text { with a } \\
\text { variety of } \\
\text { behavioural } \\
\text { disorders } \\
\text { from } \\
\text { veterinary } \\
\text { clinic }\end{array}$ & $\begin{array}{l}\text { A behaviour } \\
\text { modification } \\
\text { plan (verbal) } \\
\text { as given in } \\
\text { Iba'ñez and } \\
\text { Anzola's } 2009 \\
\text { study in } \\
\text { combination } \\
\text { with fluoxetine } \\
\text { hydrochloride } \\
\text { and clorazepate } \\
\text { dipotassium }\end{array}$ & $\begin{array}{l}\text { Clinical } \\
\text { history was } \\
\text { completed } \\
\text { using a } \\
\text { questionnaire. } \\
\text { Information } \\
\text { was collected } \\
\text { via telephone } \\
\text { at } 3 \text { points in } \\
\text { time after the } \\
\text { start of } \\
\text { therapy by } \\
\text { veterinary } \\
\text { overseers. } \\
\text { Bipolar rating } \\
\text { scale was used } \\
\text { for owners to } \\
\text { rate how much } \\
\text { the dog's } \\
\text { behaviour } \\
\text { improved and } \\
\text { their } \\
\text { compliance } \\
\text { with the } \\
\text { treatment } \\
\text { recommendati } \\
\text { ons. }\end{array}$ & $\begin{array}{l}6 \text { out } 10(60 \%) \\
\text { of dogs with } \\
\text { SA showed } \\
\text { improvements } \\
\text { in clinical } \\
\text { response. There } \\
\text { was a } \\
\text { correlation } \\
\text { between owner } \\
\text { compliance } \\
\text { with the } \\
\text { treatment } \\
\text { instructions } \\
\text { and the } \\
\text { reported } \\
\text { improvement } \\
\text { achieved. }\end{array}$ & $\begin{array}{l}\text { Capacity of } \\
\text { clorazepate to } \\
\text { control } \\
\text { anxiety was } \\
\text { more limited } \\
\text { than that of } \\
\text { fluoxetine. } \\
\text { The } \\
\text { behaviour } \\
\text { modification } \\
\text { plan is a } \\
\text { therapeutic } \\
\text { tool that, in } \\
\text { many cases, } \\
\text { requires the } \\
\text { use of } \\
\text { anxiolytic } \\
\text { drugs to } \\
\text { produce good } \\
\text { results i.e., } \\
\text { the use of } \\
\text { combination } \\
\text { therapy } \\
\text { produces } \\
\text { better results } \\
\text { than either } \\
\text { therapy used } \\
\text { alone. }\end{array}$ \\
\hline $\begin{array}{l}\text { Lem, } \\
2002^{32}, \\
\text { Canada }\end{array}$ & 1 & $\begin{array}{l}2 \\
\text { weeks }\end{array}$ & $\begin{array}{l}\text { The dog } \\
\text { was chosen } \\
\text { due to } \\
\text { excessive } \\
\text { vocalization } \\
\text { when left } \\
\text { alone }\end{array}$ & $\begin{array}{l}\text { A desensiti- } \\
\text { zation and } \\
\text { counter-condi- } \\
\text { tioning } \\
\text { program. } \\
\text { Clomipramine } \\
\text { was } \\
\text { recommend-ed } \\
\text { thereafter. }\end{array}$ & $\begin{array}{l}\text { Dog was left } \\
\text { alone and } \\
\text { monitored } \\
\text { using a } \\
\text { cassette tape } \\
\text { recording. }\end{array}$ & $\begin{array}{l}\text { The dog was } \\
\text { able to be left } \\
\text { alone for up to } \\
1 \mathrm{~h} \text { without } \\
\text { vocalization. } \\
\text { However, when } \\
\text { he was left for } \\
2 \mathrm{~h} \text {, anxiety } \\
\text { came back. }\end{array}$ & $\begin{array}{l}\text { Prudent use } \\
\text { of medication } \\
\text { can be useful } \\
\text { as an adjunct } \\
\text { to behavior } \\
\text { modification. }\end{array}$ \\
\hline $\begin{array}{l}\text { Karagian } \\
\text { nis et al, } \\
2015^{33} \text {, } \\
\text { UK }\end{array}$ & $\begin{array}{l}12 \\
\text { dogs, } \\
\text { of } \\
\text { which } \\
5 \\
\text { showe } \\
\text { d signs } \\
\text { of SRP }\end{array}$ & $\begin{array}{l}2 \\
\text { month } \\
\mathrm{s}\end{array}$ & $\begin{array}{l}\text { Advertisem } \\
\text { ents in the } \\
\text { local media } \\
\text { in the } \\
\text { Lincoln UK } \\
\text { area and } \\
\text { through } \\
\text { veterinary } \\
\text { clinics in } \\
\text { both } \\
\text { London and } \\
\text { Lincoln. }\end{array}$ & $\begin{array}{l}\text { Fluoxetine } \\
\text { chewable } \\
\text { tablets } \\
(\text { Reconcile } \\
\text { and a standard } \\
\text { behaviour } \\
\text { modification } \\
\text { plan }\end{array}$ & $\begin{array}{l}\text { Questionnaire } \\
\text { s and } \\
\text { interviews of } \\
\text { the owners. } \\
\text { Canines were } \\
\text { evaluated } \\
\text { using the } \\
\text { spatial } \\
\text { cognitive bias } \\
\text { test. }\end{array}$ & $\begin{array}{l}\text { An } \\
\text { improvement } \\
\text { in clinical } \\
\text { behaviour } \\
\text { measures and } \\
\text { the dog's } \\
\text { underlying } \\
\text { affective state. }\end{array}$ & $\begin{array}{l}\text { A behaviour } \\
\text { modification } \\
\text { plan } \\
\text { and fluoxetine } \\
\text { leads to an } \\
\text { improvement } \\
\text { in the } \\
\text { behaviour of } \\
\text { dogs with } \\
\text { SRP. This } \\
\text { improvement } \\
\text { is linked to } \\
\text { changes in } \\
\text { affective state } \\
\text { and SSRIs } \\
\text { have an } \\
\text { antidepressant } \\
\text { effect on }\end{array}$ \\
\hline
\end{tabular}




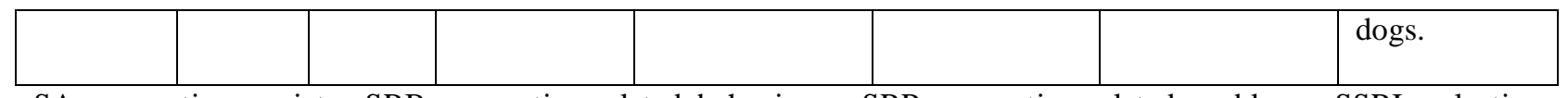

SA: separation anxiety, SRB: separation-related behaviours, SRP: separation-related problems, SSRI: selective serotonin reuptake inhibitor

Table 2:-A descriptive comparison of advice given

\begin{tabular}{|c|c|}
\hline Authors, Year & Description of the advice given \\
\hline $\begin{array}{l}\text { Herron et al, } \\
2014 \\
\text { US }\end{array}$ & $\begin{array}{l}\text {-Adopters in the treatment group received a 5-minute pre-adoption counseling session, a written } \\
\text { handout summarizing this counseling, and a food dispensing toy. Adopters in the control group } \\
\text { were not given counseling or the handout. } \\
\text {-Counseling included a description of the common signs of SA. } \\
\text {-Guidelines included recommendations such as: } \\
\text { (1) The designation of a safe home alone area } \\
\text { (2) } 20 \text { minutes of physical exercise before departures } \\
\text { (3) Downplaying departures and arrivals } \\
\text { (4) Avoiding punishment for undesirable behaviors upon their return }\end{array}$ \\
\hline $\begin{array}{l}\text { Blackwell et al, } \\
2016 \\
\text { England }\end{array}$ & $\begin{array}{l}\text {-Participants in the control group were given a leaflet containing general advice about } \\
\text { vaccinations and worming. Adopters of dogs in the treatment group received a leaflet giving } \\
\text { behavioral advice based on a previous behavior modification program (Blackwell et al., 2006). } \\
\text { The advice made relevant to newly adopted dogs entering the household for the first time. } \\
\text {-The behavioral advice included recommendations such as: } \\
\text { (1) Controlling all social interactions with their dog. } \\
\text { (2) Not punishing their dog on returning home, regardless of whether the dog had been } \\
\text { displayed anxious behaviour. } \\
\text { (3) Exercising the dog before departing, and to provide enrichment in the form of toys or } \\
\text { treats } \\
\text { (4) A systematic desensitization and counter-conditioning program, involving leaving the } \\
\text { (5) Advg for gradually increasing periods }\end{array}$ \\
\hline $\begin{array}{l}\text { Clark et al, } \\
1993 \\
\text { US }\end{array}$ & $\begin{array}{l}\text {-Obedience classes were provided on a weekly basis for the Obedience group and their dogs. } \\
\text { Classes were } 90 \text { min each for a total of } 8 \text { weeks and taught basic obedience exercises. } \\
\text {-Lectures on canine behaviour were presented during the last } 20 \text { min of each class. The materials } \\
\text { were prepared by the authors. The lectures included information about interpreting canine body } \\
\text { language, communication techniques and methods to prevent and resolve common dog } \\
\text { behaviour problems. Questions about canine behaviour were addressed after the lecture. The } \\
\text { class was encouraged to listen to the questions and answers because the topic may pertain to } \\
\text { them and their dog. The behaviour problems discussed in class included digging, chewing, } \\
\text { barking, house soiling, hyperactivity, fearfulness and jumping on people. }\end{array}$ \\
\hline $\begin{array}{l}\text { Cottam et al, } \\
2008 \\
\text { US }\end{array}$ & $\begin{array}{l}\text {-PetFax - Faxing of instructions to owners } \\
\text { 1. Avoidance of the cycle of anxiety that occurs during the owner's departure and arrival, } \\
\text { 2. Independence training at times when the owner is home, } \\
\text { 3. Short-term planned departures, } \\
\text { 4. "Employment" in the form of environmental enrichment while the owner is away, and } \\
\text { 5. An increase in daily aerobic exercise. Handouts on separation anxiety-its presentation and } \\
\text { current treatments } \\
\text {-Also included are follow-up phone calls between the owner and the certified applied animal } \\
\text { behaviorist to discuss implementation of behavior modification techniques. Clinic clients } \\
\text { received personalized management and behavior modification recommendations to help address } \\
\text { their dog's separation anxiety, including medications. }\end{array}$ \\
\hline $\begin{array}{l}\text { Butler et al, } \\
2010 \\
\text { New Zealand }\end{array}$ & $\begin{array}{l}\text {-Systematic desensitisation: Owners were instructed to place their dog in isolation with food } \\
\text { treats 3-4 times per day, with a minimum of } 1 \mathrm{~h} \text { between isolation periods. Separation periods } \\
\text { would then increase until a period of } 30-90 \text { min was reached without recurrence of separation- } \\
\text { related behaviour. After that, isolation durations were increased more rapidly. If the dog } \\
\text { displayed evidence of separation-related behaviour, owners returned to the longest period not } \\
\text { previously associated with separation-related behaviour and to proceed more gradually. }\end{array}$ \\
\hline
\end{tabular}




\begin{tabular}{|c|c|}
\hline & $\begin{array}{l}\text {-Counter-conditioning and punishment: Owners were instructed to deliver food during } \\
\text { predeparture activity, immediately before leaving the dog, and immediately after the owner } \\
\text { returned. If the dog had engaged in destructive behaviour during the owner's absence, the dog } \\
\text { was ignored for } 30 \text { min after the owner returned. Dog owners were instructed to cease delivery } \\
\text { of positive punishment (verbal or physical) for separation-related problem behaviours. } \\
\text {-4.3. Exercise and stay training All dog owners were instructed to exercise their dog for at least } \\
15 \text { min every day. Owners also received instructions on how to train their dogs to "stay", using } \\
\text { positive reinforcement for lying calmly when given the "stay" command, in neutral settings and } \\
\text { then during pre-departure activity. Owners were instructed to reward calm behaviour around the } \\
\text { house, to ignore excited behaviour, and to prevent the dog from following the owner around the } \\
\text { house by shutting doors. }\end{array}$ \\
\hline $\begin{array}{l}\text { Podberscek et } \\
\text { al,, 1999, UK }\end{array}$ & $\begin{array}{l}\text { A four-phase plan to modify dog's' behaviour are given to owners. } \\
\text { 1. Stop scolding their dog for separation-anxiety related behaviours and limit the amount } \\
\text { of interaction with their dogs. Leave dog with owner's clothes, appropriate chew items } \\
\text { that are not available when the owner is at home, tape recordings of owner's voice } \\
\text { switched on. } \\
\text { 2. Accustom the dog to being separated from its owners when they are at home and awake } \\
\text { for varying lengths of time and at different times of the day. Dividing doors to be shut } \\
\text { during the separation to deny the dogs from following their owners. } \\
\text { 3. Dogs which before the trial slept in the owner's bedroom should be gradually moved } \\
\text { by means of a mobile barrier which is gradually relocated to oblige the dog to sleep } \\
\text { closer to, and eventually where it is left when the owners are separated for it during the } \\
\text { day. } \\
\text { 4. Owners to start the practice of putting on their outdoor clothing, setting burglar alarms } \\
\text { etc when they have separated their dog from them, as in phase 2, but should not } \\
\text { actually leave the home. }\end{array}$ \\
\hline $\begin{array}{l}\text { Takeuchi et al, } \\
2000, \text { US }\end{array}$ & $\begin{array}{l}\text { Discharge instructions were individualized for each dog. Several instructions including: no } \\
\text { punishment; increase exercise; provide regular relaxation training (sit-stay protocol); crating; } \\
\text { downplay departure; give a special toy when leaving; dissociate the cues of departure, such as } \\
\text { picking up keys, putting on shoes, and turning off lights, by performing cues without leaving } \\
\text { (uncoupling cues); desensitize the dog to owner's departure and absence by leaving for many } \\
\text { short periods (desensitization); and medicate the dog were provided. }\end{array}$ \\
\hline $\begin{array}{l}\text { Iba'ñez and } \\
\text { Anzola, 2009, } \\
\text { Spain }\end{array}$ & $\begin{array}{l}\text { This plan consisted of } 3 \text { basic steps designed to stop unwanted behaviors and reward preferred } \\
\text { behaviors that were incompatible with the performance of undesirable behaviors. } \\
\text { 1. To stop rewards for undesirable behaviors. } \\
\text { 2. To follow a passive behavior modification plan which included: (1) rewarding only } \\
\text { relaxed behavior; (2) eliminating reinforcement of anxious behaviors by reassuring or } \\
\text { patting the dog when it showed clinical signs of fear or anxiety; (3) setting a routine for } \\
\text { feeding and playing times; (4) spending } 20 \text { minutes per day in } 4 \text { sessions ( } 5 \text { minutes } \\
\text { each) playing or otherwise actively interacting with the dog. } \\
\text { 3. To begin active behavior modification designed to teach the dogs to relax when they } \\
\text { would otherwise be engaged in the problem behavior, in exchange for which the dog } \\
\text { was given a food or play reward. }\end{array}$ \\
\hline $\begin{array}{l}\text { Blackwell et al, } \\
2006, \text { UK }\end{array}$ & $\begin{array}{l}\text { The programme was divided into three parts (A, B and C). } \\
\text { A. Owner to control his or her attention and ignore the dog's attention-seeking behaviour. } \\
\text { B. Part B involved desensitising the dog to being left alone, by gradually increasing the } \\
\text { time that its owner was out of sight, and by preventing it from predicting when its } \\
\text { owner was preparing to leave, by changing the owner's behaviour patterns. } \\
\text { C. Owners were advised to give the dog things to do when left alone, such as providing } \\
\text { treat-filled toys to play with and something that carried the owners' scent, and after } \\
\text { returning home, not to punish the dog for any unacceptable behaviour. Advice about } \\
\text { feeding and exercise was also given in part C so that they were standardised throughout } \\
\text { the trial. }\end{array}$ \\
\hline $\begin{array}{l}\text { Pineda et al, } \\
\text { 2013, Spain }\end{array}$ & advice given in Iba'ñez and Anzola's 2009 study. \\
\hline
\end{tabular}




\begin{tabular}{|l|l|}
\hline $\begin{array}{l}\text { Lem, 2002, } \\
\text { Canada }\end{array}$ & $\begin{array}{l}\text { Systematic desensitization and counter-conditioning program. Calm and relaxed behavior were } \\
\text { rewarded. }\end{array}$ \\
\hline $\begin{array}{l}\text { Karagiannis et } \\
\text { al, 2015, UK }\end{array}$ & $\begin{array}{l}\text { At home: Interact with dog only at your initiative and when the dog is relaxed. } \\
\text { Praise the dog when it is relaxed. Gradually teach your dog to stay calm and to be alone by } \\
\text { gradually increasing the distance and time from the dog. Give departure cues at times other than } \\
\text { departure. Praise calm behaviour if appropriate. }\end{array}$ \\
$\begin{array}{l}\text { Before leaving: Show indifference to the dog for } 20 \text { to } 30 \text { minutes prior to going out. While } \\
\text { leaving, give a special toy or a treat to distract the dog and remove the item on return. Do not } \\
\text { interact with the dog just before leaving. } \\
\text { When returning:Ignore the dog's excessive greeting until he is quiet and relaxed. } \\
\text { Interact with your dog only on your initiative and only when he/she is quiet. } \\
\text { Reward calm behaviour. } \\
\text { Do not reprimand dog for destructive behaviour or for urinating or defecating in the house. }\end{array}$ \\
\hline
\end{tabular}

\section{Bibliography:-}

$$
\text { -End- }
$$

1. Herron ME, Lord LK, Husseini SE.(2014) Effects of preadoption counselling on the prevention of separation anxiety in newly adopted shelter dogs. Journal of Veterinary Behaviour .9(1):13-21.

2. Bamberger, M., Houpt, K.A.(2006) Signalment factors, comorbidity and trends in behavior diagnosis in dogs; 1664 cases (1991-2001). J. Am. Vet. Med. Assoc. 229(10): 1591-1601

3. Horwitz, D. F. (2000). Diagnosis and treatment of canine separation anxiety and the use of clomipramine hydrochloride (Clomicalm). Journal of the American Animal Hospital Association. 36(2): 107-109.

4. Voith, V. L, \&Borchelt, P. L. (1996). Readings in companion animal behavior. In V. L. Voith \& P. L. Borchelt (Eds.), Separation anxiety in dogs (pp. 124-139). Trenton, NJ: Veterinary Learning Systems.

5. Schwartz, Stefanie (2003) Separation anxiety syndrome in dogs and cats. Journal of the American Veterinary Medical Association. 222(11): 1526-1532

6. Patronek GJ, Glickman LT, Back AM, et al. (1996) Risk factors for relinquishment of dogs to an animal shelter. J Am Vet Med Assoc. 209(4):738-42.

7. Takeuchi Y, Houpt KA, Scarlett JM.(2000) Evaluation of treatments for separation anxiety in dogs. J Am Vet Med Assoc. 217(3): 342-345

8. Kurachi et al (2017) Dogs predisposed to anxiety disorders and related factors in Japan Appl. Anim.Behav. Sci. 196: 69-75

9. G. Flannigan, N.H. Dodman (2001) Risk factors and behaviours associated with separation anxiety in dogs J. Am. Vet. Med. Assoc. 219(14): 460-466

10. Patronek, G.J. \& Glickman, Larry \& Beck, Alan \& McCabe, G.P. \& Ecker, C. (1996). Risk Factors For Relinquishment Of Dogs To An Animal Shelter. Journal of the American Veterinary Medical Association. 209(3): 572-581.

11. Brayley, Clarissa \& Montrose, Tamara. (2016). The effects of audiobooks on the behaviour of dogs at a rehoming kennels. Applied Animal Behaviour Science. 174: 111-115.

12. C. Marston, Linda \& Bennett, Pauleen. (2003). Reforging the bond - Towards successful canine adoption. Applied Animal Behaviour Science - Appl. Anim.Behav. Sci. 83(3): 227-245.

13. Sherman BL and Mills DS.(2008) Canine anxieties and phobias: an update on separation anxiety and noise aversions. Veterinary Clinics of North America: Small Animal Practice 38(5): 1081-1106.

14. Ionel, Papuc\&Deac, Lucia \& Cristian, Purdoiu. (2013). The behavioral therapy for separation anxiety in dog. Bulletin of University of Agricultural Sciences and Veterinary Medicine Cluj-Napoca. Veterinary Medicine. 70(1): 121-127.

15. Podberscek, AL \& Hsu, YY \&Serpell, James. (1999). Evaluation of clomipramine as an adjunct to behavioural therapy in the treatment of separation-related problems in dogs. The Veterinary record. 145(13). 365-369.

16. Miguel Iba'ñeza, Bernadette Anzola. (2009). Use of fluoxetine, diazepam, and behavior modification as therapy for treatment of anxiety-related disorders in dogs. Journal of Veterinary Behavior. 4(6): 223-229

17. S. Pineda, B. Anzola, A. Olivares, M. Ibáñez. (2014) Fluoxetine combined with clorazepate dipotassium and behaviour modification for treatment of anxiety-related disorders in dogs. The Veterinary Journal 199 (3) $387-$ 391

18. Cottam, Nicole \& Dodman, Nicholas \& Moon-Fanelli, Alice \& J Patronek, Gary. (2008). Comparison of Remote Versus In-Person Behavioral Consultation for Treatment of Canine Separation Anxiety. Journal of applied animal welfare science : JAAWS. 11(1): 28-41.

19. Jayne Blackwell, Emily \& Casey, Rachel \& W. S. Bradshaw, John. (2016). Efficacy of written behavioral 
advice for separation-related behavior problems in dogs newly adopted from a rehoming center. Journal of Veterinary Behavior: Clinical Applications and Research. 12: 13-19

20. Butler, Rynae\&Sargisson, Rebecca \&Elliffe, Douglas. (2011). The efficacy of systematic desensitization for treating the separation-related problem behaviour of domestic dogs. Applied Animal Behaviour Science. 129(24): $136-145$

21. E. Blackwell, R. A. Casey, J. W. S. Bradshaw (2006) Controlled trial of behavioural therapy for separationrelated disorders in dogs. The Veterinary Record 158(16):551-554

22. Gail. I Clark, William N. Boyer (1993) The effects of dog obedience training and behavioural counselling upon the human-canine relationship. Applied Animal Behaviour Science. 37(2): 147-159

23. Dodman, N., Donnelly, R., Shuster, L., Mertens, P., Rand, W., Miczek, K., 1996. Use of fluoxetine to treat dominance aggression in dogs. Journal of the American Veterinary Medical Association 209(9): 1585-1587.

24. Reisner, I., (2006). An overview of aggression. In: Horwitz, D., Mills, D., Heath, S. (Eds.), BSAVA Manual of Canine and Feline Behavioural Medicine. British Small Animal Veterinary Association:181-194.

25. Klein, N.F., Evans, F., (1989). Anxiety and learning to formulate hypothesis. Journal of Educational Psychology 60(6): 465-475.

26. Lisanna Lamb, Nadja Affenzeller, Lynn Hewison, Kevin James McPeake, Helen Zulch, Daniel S. Mills (2018) Development and application of the lincoln adherence instrument record for assessing client adherence to advice in Dog Behavior consultations and success Frontiers in veterinary science 5:37

27. Shalvey, Emma; McCorry, Mark; Hanlon, Alison.(2019) Exploring the understanding of best practice approaches to common dog behaviour problems by veterinary professionals in Ireland. Irish Veterinary Journal 72(1)

28. Borchelt PL, Voith VL. (1982) Diagnosis and treatment of separation-related behavior problems in dogs. Vet Clin North Am Small AnimPract 12(4):625-635.

29. Mugford, R.A., 2002. Canine behavioural therapy. In: Serpell, J. (Ed.), The Domestic Dog: Its Evolution, Behaviour and Interactions with People. London, UK, pp.141-143.

30. Crowell-Davis, S., Murray, T., 2006. Veterinary Psychopharmacology. Blackwell Publishing Ltd., Oxford, p. 51.

31. Pharmacological Treatment in Behavioural Medicine: The Importance of Neurochemistry, Molecular Biology and Mechanistic Hypotheses. (2001) The Veterinary Journal, 162, 9-23.

32. Michelle Lem. (2002) Behavior modification and pharmacotherapy for separation anxiety in a 2-year-old pointer cross. Can Vet J Volume 43.

33. Christos I Karagiannis, Oliver HP Burman and Daniel S Mills. (2015). Dogs with separation-related problems show a "less pessimistic" cognitive bias during treatment with fluoxetine (Reconcile ${ }^{\mathrm{TM}}$ ) and a behaviour modification plan. BMC Veterinary Research.

34. Brian J. Burton. (2018). Literature review: Behaviour modification for canine separation anxiety. IAABC Journal.

35. Sargisson R. (2014). Canine separation anxiety: strategies for treatment and management. Dove Press

36. Barbara L. Sherman. (2008). Separation Anxiety in Dogs. Compendium on Continuing Education for the Practising Veterinarian -North American Edition. 